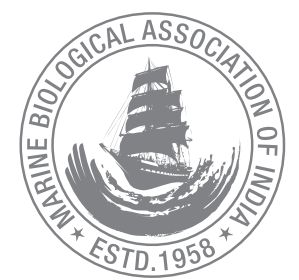

\title{
Mariculture of Kappaphycus alvarezii in the coastal waters of Palk Bay: crisis due to climate change or carrying capacity?
}

\author{
P. Kaladharan*, B. Johnson' ${ }^{1}$ and Bindu Sulochanan ${ }^{2}$ \\ ICAR- Central Marine Fisheries Research Institute, Kochi-682 018, Kerala, India. \\ ${ }^{1}$ Regional Centre of ICAR- Central Marine Fisheries Research Institute, Mandapam Camp, Ramanthapuram-623 520. \\ ${ }^{2}$ Research Centre of ICAR- Central Marine Fisheries Research Institute, Hoige Bazar, Mangalore-575 001. \\ *Correspondence e-mail: kaladharanep@gmail.com
}

Received: 04 May 2019 Accepted: 19 Sep 2019 Published: 30 Oct 2019

Short communication

\begin{abstract}
Gradual expansion in the cultivation of carrageenan yielding red alga, Kappaphycus alvarezii in the Palk Bay from the year 1996 reached its peak in 2012. Large scale introduction of numerous rafts bearing propagules of this marine alga within the bay area registered tremendous decline in the production due to decay of thallus and poor growth since August 2013. At present more than $50 \%$ of the rafts were abandoned in the shore due to drastic reduction in yield and for want of sufficient seed material required for subsequent crop. Analysis of data on SST and nutrient profile of seawater from Palk Bay area demands need for urgent carrying capacity studies for optimum biomass production. It is advisable to restrict the number of rafts ( $3 \times 3 \mathrm{~m}$ size) to 225 and seed quantity of 5.4 to 6.0 tonnes per hectare.
\end{abstract}

Keywords: Seaweed mariculture, Kappaphycus alvarezii, nutrient profile, carrying capacity, Palk Bay

\section{Introduction}

Seaweeds are cultivated for their commercial importance of phycocolloids such as agar, algin and carrageenan besides, their use as food, fodder, biofertilizers, source of enzymes, pigments, nutraceuticals, drugs, antibiotics etc. In India seaweeds are harvested from natural beds for seaweed industries along Tamil Nadu and Gujarat coasts since 1966. Mariculture of seaweeds in India mostly started with cultivation of Gracilaria edulis due to its high regenerative capacity. Very recently the cultivation of Kappaphycus, an exotic carrageenophyte introduced in Indian waters found to be very encouraging and will prove to be answer to overcome the shortage for raw materials for extraction of carrageenan and will generate sufficient revenue. Already countries like China, Japan, Philippines, Korea are widely cultivating seaweeds and wild harvests are regulated. Nowadays cultivation of certain species of seaweeds such as Laminaria, Gracilaria, Porphyra, Undaria and Kappaphycus are being successfully carried out as marine plantation crops.

The Central Salt and Marine Chemicals Research Institute (CSMCRI) introduced Kappaphycus alvarezii, a fast growing seaweed in the Diu coast (Gujarat) in 1995 for experiments in confined waters from the Philippines (Mairh et al., 1995). After successful introduction and acclimatization, the CSMCRI transferred the 
material and the technology to PepsiCo only after convincing itself that its cultivation would be ecologically safe to cultivate in the Palk Bay region during the year 2000 (Mantri et al., 2017). The species is a source of $k$-carrageenan, a gel-forming agent widely used in the pharmaceutical and food industries. Among the algal polysaccharides, $k$-carrageenan enjoys prime significance as it is used in more than 200 applications in confectionary or pharmaceutical industries. This alga is commercially cultivated in the open sea in a large area by the Pepsi Foods Limited (PFL) in the beginning and later years by $\mathrm{M} / \mathrm{s}$. Aquagri Processing Ltd with the help of fishermen with whom the companies have "buy back" agreement (Periyasamy and Kaliaperumal, 2019). Mariculture of Kappaphycus alvarezi in the East coast of India (Fig. 1) is the only aquaculture activity which could pay a royalty of Rs. 38.5 lakhs to the National Biodiversity Authority (Down to Earth, 2012). The introduction and mariculture of $K$. alvarezii and the subsequent utilization processes earned many patents to the CSIR-CSMCRI as shown below:

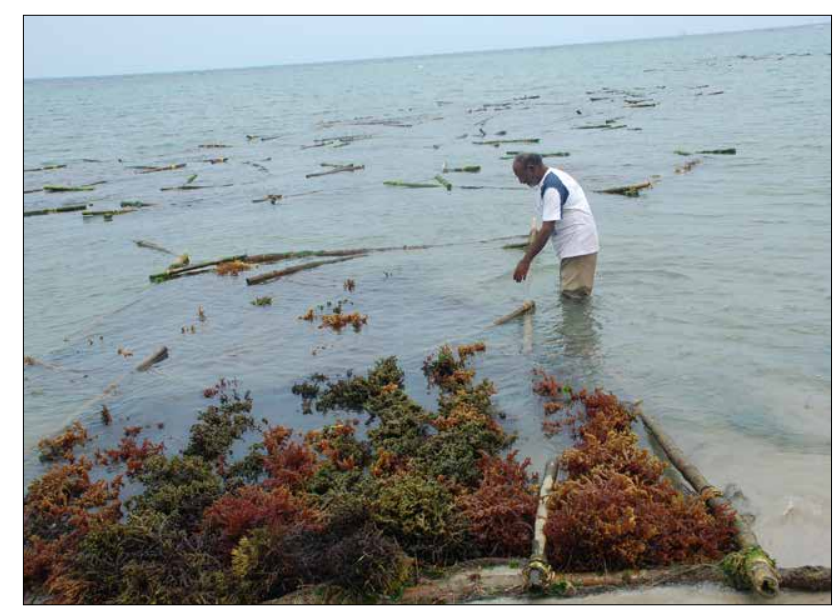

Fig. 1. Cultivation of Kappaphycus alvarezii in Rameswaram for carrageenan extraction

\section{Material and methods}

Data on Kappaphycus production details through mariculture along the coastal districts of Tamil Nadu such as annual production values and the number of rafts deployed in the coastal waters of Tamil Nadu during the years 2012- 2018 were collected periodically from the seaweed farmers by employing pre-tested interview schedules (Johnson et al., 2017). The in situ data on sea surface temperature (SST), dissolved ammonia and the nutrients such as Phosphate, Silicate, Nitrate and Nitrite were generated from the seawater samples collected along the seaweed cultivation sites in the Palk Bay and analysed using the standard procedures (APHA., 1998). Monthly SST data of Kappaphycus culture sites in Palk Bay $\left(9^{\circ} \mathrm{N} ; 79^{\circ} \mathrm{E}\right)$ for the period from July 2002 - December 2018 were archived from MODIS- Aqua Sensor with $4 \mathrm{~km}$ spatial resolution (Shafeeque et al., 2019) from the Asia -Pacific Data Research Centre (APDRC web site: http://apdrc.soest.hawaii.edu).

\section{Results and discussion}

Presently large scale mariculture of $K$. alvarezii is being carried out at Mithapur, Okha and Beyt Dwaraka along Gujarat coast and Ramanathapuram, Thanjavur, Pudukottai, Tuticorin and Kanyakumari Districts of Tamil Nadu coast (Johnson et al., 2017; Mantri et al., 2017). The economic analysis of mariculture of $K$. alvarezii and that of wild collection of seaweeds along the Ramanathapuram coast is made available recently by Johnson et al. (2017). From 2013 onwards a sharp decline in the mariculture production of $K$. alvarezii was noticed from the peak of 1500 tonnes dry weight during 2012 (Fig. 2). It is evident in many cultivation sites along the Palk Bay region that more than 50\% of the rafts were abandoned in the shore due to the reduction in yield and for want of sufficient seed material required for subsequent crop (Fig. 3). It is known that from the year 2013 onwards, coastal waters along Pudukottai and Thanjavur districts of Tamil Nadu registered higher production of Kappaphycus than that of Ramanathapuram District (Table 1) which had maximum

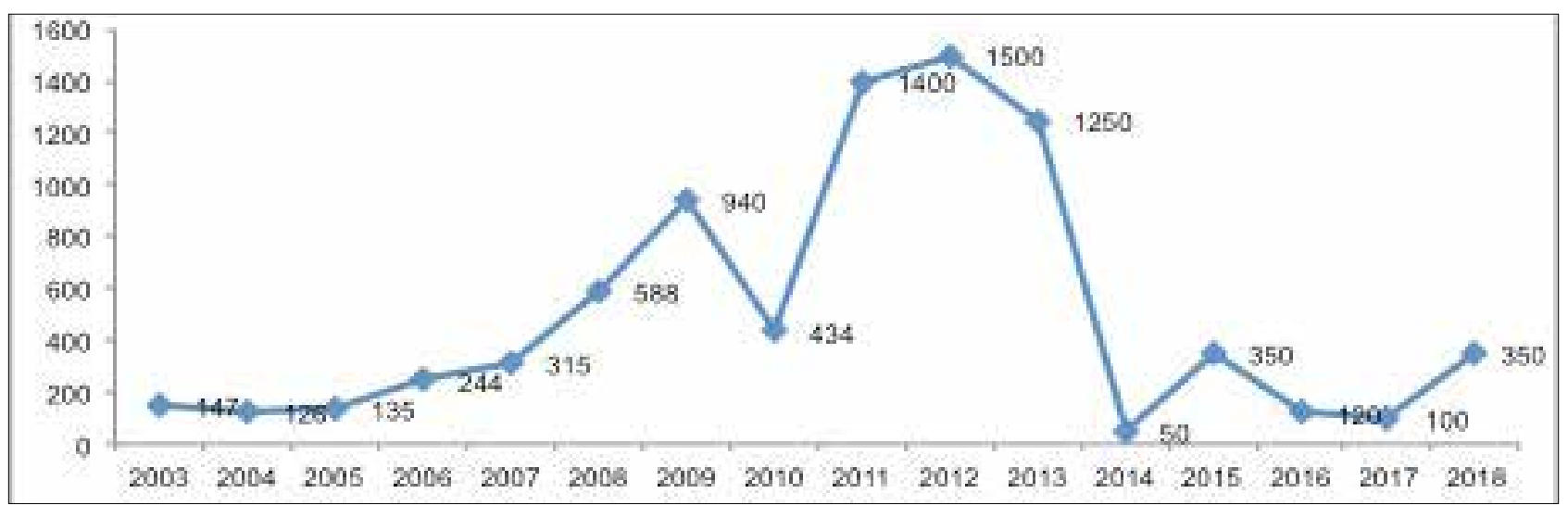

Fig. 2. Kappaphycus production from Tamil Nadu coast (tonnes dry weight) 


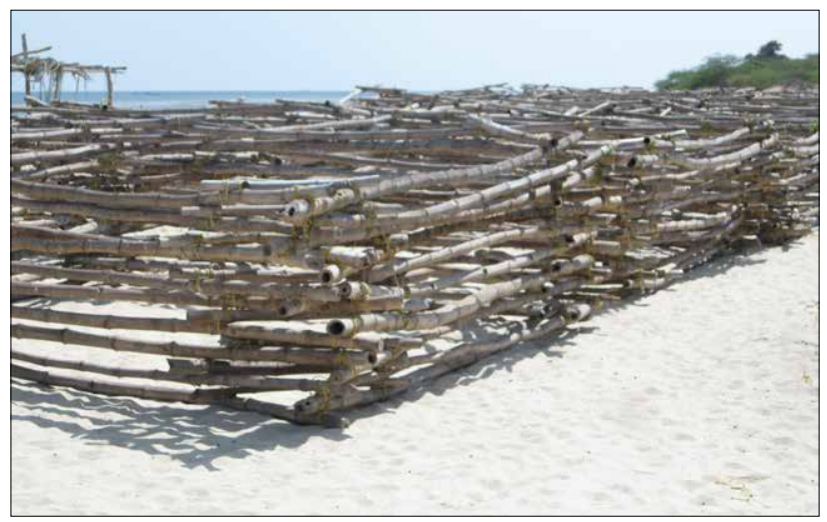

Fig. 3. View of bamboo rafts beached on shore due to non availability of adequate seed materials

number of rafts/ culture units (Table 2) and production hitherto the year 2014.

Various reasons were presumed to the decline in Kappaphycus production through sea farming in Ramanathapuram coast such as ice- ice disease (Largo, 2002; Arasamuthu and Edward, 2017) crowding of seaweed culture rafts without understanding Table 1. District-wise Kappaphycus production (tonnes dry weight) from Tamil Nadu coast

\begin{tabular}{llrrrrrrr}
\hline S. No & Name of the district & 2012 & 2013 & 2014 & 2015 & 2016 & 2017 & 2018 \\
\hline 1 & Ramanathapuram & 1000 & 550 & 10 & 100 & 20 & 25 & 100 \\
\hline 2 & Pudukottai \& Thanjavur & 350 & 500 & 30 & 200 & 80 & 60 & 200 \\
\hline 3 & Tuticorin\& Kanyakumari & 150 & 200 & 10 & 50 & 20 & 15 & 50 \\
\hline & Total & 1500 & 1250 & 50 & 350 & 120 & 100 & 350 \\
\hline
\end{tabular}

Table 2. Number of rafts/ culture units being used for Kappaphycus cultivation in Tamil Nadu

\begin{tabular}{lllll}
\hline \multirow{2}{*}{ S.No } & \multirow{2}{*}{ Name of the districts in Tamil Nadu } & \multicolumn{3}{l}{ No. of rafts used for cultivation } \\
\cline { 3 - 5 } & & 2013 & 2015 & 2018 \\
\hline 1 & Ramanathapuram & 15000 & 2500 & 1750 \\
\hline 2 & Pudukottai \& Thanjavur & 6500 & 2500 & 4000 \\
\hline 3 & Tuticorin \& Kanyakumari & 5500 & 1200 & 1250 \\
\hline & Total & 27000 & 6200 & 6500 \\
\hline
\end{tabular}

carrying capacity (Kaladharan et al., 2014) and climate change induced fluctuations in diatoms (Ganesh et al., 2014). Loss of biomass of thallus and tender apices of seaweeds are the outcomes of ice-ice disease. In Palk Bay, Arasamuthu and Edward (2017) have noticed culturable bacterial populations in both healthy as well as ice-ice infected thallus of Kappaphycus being cultivated and the degree of infection was more during summer months. However, it is well known that bacterial infections and pest infestations in farmed seaweeds are mainly due to stresses from rapid shifts in water quality followed by fungal and bacterial infestations (Largo, 2002; Laureiro et al., 2017).

Monthly SST data for the period July 2002 to December 2018 obtained from MODIS-Aqua Sensor (APDRC website http:// apdrc.soest.hawaii.edu) relevant to Kappaphycus farming sites in Palk Bay also indicate no major anomaly in the sea surface temperature, showing the maximum of $31.5^{\circ} \mathrm{C}$ only and the minimum of $26^{\circ} \mathrm{C}$ during the year (Fig. 4) which could not support the claim of reduced production of Kappaphycus due to SST increase. Abhilash et al. (2019) have found no adverse variation in water quality parameters due to Kappaphycus farming in Palk Bay after analyzing the three year study results from the seaweed culture as well as the control reference sites and any slight variation in water quality are only local and site specific. Our in situ observation of SST and dissolved nutrients using the standard procedures from the seaweed farming areas in Palk Bay showed a four year mean temperature of $30.48^{\circ} \mathrm{C}$ during the month of August while, the same month during the year 2014 registered only $31.7^{\circ} \mathrm{C}$. However, the dissolved nutrient content in the seaweed farming sites registered considerable decrease in 2014 over the previous years (Table 3).

This reduction in dissolved nutrients in the seaweed farming site may be very possibly due to the overcrowding of Kappaphycus culture rafts/ units being carried out in the shallow near shore waters successively. Horizontal expansion of the culture units/

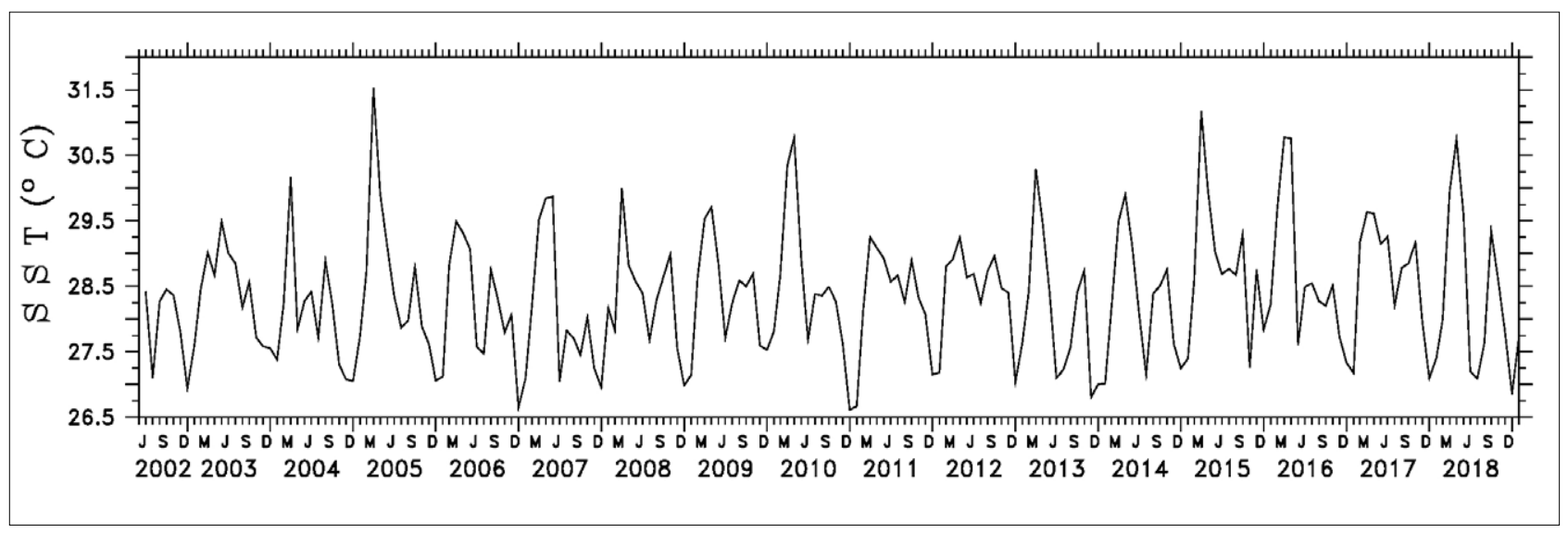

Fig. 4. The time series map of SST data from 2002 to 2018 relevant to Kappaphycus farming sites in Palk Bay 
Table 3. In situ observations on dissolved nutrients and SST in Palk Bay

\begin{tabular}{|c|c|c|c|c|c|c|c|}
\hline $\begin{array}{l}\text { Parameters } \rightarrow \\
\text { Period } \downarrow\end{array}$ & $\mathrm{SST}\left({ }^{\circ} \mathrm{C}\right)$ & $\mathrm{PO}_{4}(\mu \mathrm{gat} / \mathrm{l})$ & $\mathrm{SiO}_{3}(\mu \mathrm{gat} / \mathrm{l})$ & $\mathrm{NO}_{2}(\mu \mathrm{gat} / \mathrm{l})$ & $\mathrm{NO}_{3}(\mu \mathrm{gat} / \mathrm{l})$ & $\mathrm{NH}_{3}(\mu \mathrm{gat} / \mathrm{l})$ & References \\
\hline August 2005 & $31.0 \pm 1.27$ & $0.044 \pm 0.00$ & $1.065 \pm 0.08$ & $0.555 \pm 0.06$ & $3.401 \pm 0.264$ & NA & Bindu and Muniyandi, 2005 \\
\hline August 2006 & $29.2 \pm 0.94$ & $0.438 \pm 0.02$ & $1.811 \pm 0.03$ & $0.162 \pm 0.03$ & $0.78 \pm 0.06$ & NA & Bindu et al., 2011 \\
\hline August 2007 & $32.2 \pm 1.44$ & $0.063 \pm 0.00$ & $5.744 \pm 1.28$ & $0.632 \pm 0.03$ & $1.105 \pm 0.84$ & $11.18 \pm 1.07$ & Bindu et al., 2011 \\
\hline August 2008 & $29.5 \pm 1.17$ & $\mathrm{BDL}$ & $12.47 \pm 1.34$ & $0.34 \pm 0.11$ & $0.636 \pm 0.052$ & $2.042 \pm 0.08$ & Gopakumar et al., 2009 \\
\hline Mean of the above & 30.48 & 0.182 & 5.27 & 0.422 & 1.48 & 6.61 & Present communication \\
\hline August 2014 & $31.7 \pm 1.83$ & $0.005 \pm 0.00$ & $0.09 \pm 0.01$ & $0.003 \pm 0.00$ & $0.017 \pm 0.004$ & $1.09 \pm 0.07$ & Present communication \\
\hline
\end{tabular}

$($ mean $\pm S D, n=4)$

rafts towards deeper areas with adequate spacing can definitely help increase the biomass production as crowding of rafts hinder the exchange of warm (due to shallow depth) with fresh and nutrient laden seawater. When bamboo rafts of $3 \times 3 \mathrm{~m}$ is made and culture ropes tied to the raft at $15 \mathrm{~cm}$ interval 400 seeding points (knots) will be available. From the optimization experiments for Gracilaria edulis farming (Kaladharan et al., 1996) it is advisable to restrict quantity of seed per knot $(60 \mathrm{~g}$ as against the current $150 \mathrm{~g}$ : Mantri et al., 2017; Periyasamy and Kaliaperumal, 2019) and the number of rafts to 225 in a hectare area by maintaining minimum $4 \mathrm{~m}$ spacing between successive rafts which will facilitate free flow of ambient water ensuring optimum growth and production of crop. If long rope or net sleeves (net tube) method is used instead of rafts, 50 ropes/ net sleeves of $100 \mathrm{~m}$ long can be accommodated in a hectare area allowing $2 \mathrm{~m}$ spacing between adjacent ropes/ net tubes. Hence the maximum permissible quantity of seed stock in a hectare should be well within 5.4 to 6.0 tonnes and the number of rafts to be 225 and long ropes or net sleeves to be 50 recommended for optimum production.

\section{Acknowledgements}

The authors record their sincere thanks to The Director, ICARCMFRI for the encouragements received and to Dr. M. Shafeeque, Senior Research Fellow for accessing the monthly SST data from the APDRC website and designing the SST map.

\section{References}

Abhilash, K. R., R. Sankar, R. Purvaja, S. V. Deepak, C. R. Sreeraj, P. Krishnan, V. Sekar, Amit K. Biswas, G. Kumarapandiyan and R. Ramesh. 2019. Impact of long-term seaweed farming on water quality: a case study from Palk Bay, India. J. Coast Conserv. 23(2):485-499.

APHA .1998. Standard Methods for the Examination of Water and Wastewater $\left(20^{\text {th }}\right.$ Ed.). APHA, AWWA,WEF., Washington, DC 20005-2605, 350 pp.

Arasamuthu, A. and J. K. P. Edward. 2017. Occurrence of ice-ice disease in seaweed Kappaphycus alvarezii in Gulf of Mannar and Palk bay, Southeastern India. Indian J. Geo. Mar. Sci., 47(6): 1208-1216.

Bindu, S. and K. Muniyandi. 2005. Hydrographic parameters off Gulf of Mannar and Palk Bay during a year of abnormal rainfall. J. Mar. Biol. Ass. India, 47(2):198-200

Bindu, S., A. K. Kumaraguru and L. S. Korabu. 2011. Hydrological conditions in seagrass beds in Palk Bay and Gulf of Mannar, southeast coast of India. J. Mar. Biol. Ass. India, 53(1):108-115.
Down to Earth. 2012. Curious case of seaweed. Down to Earth، 15th October 2012: 23-24.

Ganesh, T., S. K. Mandal, N. Monisha, J. Malarvizi, G. Ajay and R. Jennifer. 2014 Dominance of Rhizosolenia in Palk Bay: Does Kappaphycus cultivation play any role? In: Zacharia, P. U., P. Kaladharan, Molly Varghese, N. K. Sanal, Rekha J. Nair and N. Aswathy (Eds.) Marine Ecosystem Challenges and Opportunities (MECOS 2), Book of abstracts, Marine Biological Association of India, December 2-5, 2014 Kochi, p.123-125.

Gopakumar, G., Bindu Sulochanan and V. Venkatesan. 2009. Bloom of Noctiluca scintillans (Macartney) in Gulf of Mannar, southeast coast of India. J. Mar. Biol. Ass. India, 51 (1):75 - 80

Johnson, B., R. Narayanakumar, K. Abdul Nazar, P. Kaladharan and G. Gopakumar. 2017. Economic analysis of farming and wild collection of seaweeds in Ramanathapuram District, Tamil Nadu. Indian J. Fish., 64(4): 94-99.

Kaladharan, P., K. Vijayakumaran, V. S. K. Chennubhotla. 1996. Optimization of certain physicalparameters for the mariculture of Gracilariaedulis in Minicoy lagoon of Laccadive archipelago. Aquaculture, 139: 265-270.

Kaladharan, P., B. Johnson and K. Shanmuganathan. 2014. Mariculture of Kappaphycus alvarezii in the Palk Bay- Need for carrying capacity studies. Presented to National Seminar Algae for Sustainable Agriculture TNAU- Agricultural College and Research Institute, Madurai, September 29-30, 2014 Madurai, 77 pp.

Largo, D. B. 2002. Recent developments in seaweed diseases. In: A.Q. Hurtado, N.G. Guanzon, Jr., T. R. de Castro-Mallare, and M. R. J. Luhan (Eds.) Proceedings of the National Seaweed Planning Workshop held on August 2-3, 2001, SEAFDEC Aquaculture Department, Tigbauan, Iloilo, p. 35-42.

Laureiro, R. R., A. Q. Hurtado and A.T. Critchley. 2017. Impacts of AMPEP on epiphytes and diseases in Kappaphycus and Eucheuma cultivation. In: Tropical Seaweed Farming Trends, Problems and Opportunities. doi.,10.1007/978-3319-63498-2 6 .

Mairh, O. P., S. T. Zōdape, A. Tewari and M. R. Rajyaguru. 1995. Culture of marine red alga Kappaphycus striatum (Schmitz) Doty on the Saurashtra region, west coast of India. Indian J. Mar. Sci., 24: 24-31.

Mantri V. A., K. Eswaran, M. Shanmugam, M. Ganesan, V. Veeragurunathan, S. Thiruppathi, C. R. K. Reddy and A. Seth. 2017. An appraisal on commercial farming of Kappaphycus alvarezii in India: success in the diversification of livelihood and prospects. J. Appl. Phycol., 29: 335-357.

Periyasamy, C. and N. Kaliaperumal. 2019. Red seaweed Kappaphycus cultivation- A Lucrative livelihood for Indian fisherfolk. Aquaculture Spectrum, 2(1): 12-23.

Shafeeque, M., P. Shah, T. Platt, S. Sathyendranath, N. N. Menon, A. N. Balchand and G. George. 2019. Effect of precipitation on Chlorophyll-a in an upwellingdominated region along the west coast of India. In: Jithendran, K. P., Saraswathy, R., Balasubramanian, C. P., Kumaraguru Vasagam, K. P., Jayasankar, V., Raghavan, R., Alavandi, S. V., and Vijayan, K. K. (eds.), World Brackishwater Aquaculture Conference 2019 (BRAQCON), J. Coast. Res., Special Issue No. 86, (in press). 